\title{
Retraction
}

\section{Retracted: An Inverse Spectral Problem for the Sturm-Liouville Operator on a Three-Star Graph}

\author{
International Scholarly Research Notices \\ Received 9 July 2014; Accepted 9 July 2014; Published 29 October 2014 \\ Copyright (C) 2014 International Scholarly Research Notices. This is an open access article distributed under the Creative Commons \\ Attribution License, which permits unrestricted use, distribution, and reproduction in any medium, provided the original work is \\ properly cited.
}

This paper [1] has been retracted as it is essentially identical in content with the published article "Determination of SturmLiouville operator on a three-star graph from four spectra," by Dehghani Tazehkand and Akbarfam, published in Acta Universitatis Apulensis No. 32/2012, pp. 147-172.

\section{References}

[1] I. Dehghani Tazehkand and A. J. Akbarfam, "An inverse spectral problem for the Sturm-Liouville operator on a three-star graph," ISRN Applied Mathematics, vol. 2012, Article ID 132842, 23 pages, 2012. 